\title{
FAKTOR RISIKO DERMATITIS TANGAN PADA PEKERJA TRADISIOAL INDUSTRI GERABAH (SEBUAH STUDI OBSERVASIONAL)
}

\author{
RISK FACTORS OF HAND DERMATITIS IN TRADITIONAL POTTERY INDUSTRY \\ WORKERS
}

(AN OBSERVATIONAL STUDY)

\author{
Ratih Pramuningtyas, Delima Anggraini Hudini \\ Departemen Ilmu Kesehatan Kulit dan Kelamin Fakultas Kedokteran UMS \\ Korespondensi: Ratih Pramuningtyas. Email: rp110@ums.ac.id
}

\begin{abstract}
ABSTRAK
Dermatitis tangan (DT) adalah bentuk dermatitis okupasional yang sering terjadi, karena tangan merupakan bagian tubuh yang paling sering terkena (80\%) akibat sering terpapar bahan kimia dan lingkungan.Dermatitis tangan sering berhubungan dengan pekerjaan, salah satunya industri gerabah tradisional.Tanah liat sebagai bahan utama industri gerabah mengandung bahan yang berpotensi iritan dan allergen.Frekuensi serta faktor risiko yang berpengaruh pada frekuensi DT pada industri gerabah belum diketahui.Tujuan penelitian adalah mengetahui frekuensi kejadian DT dan faktor risiko yang berpengaruh terhadap DT pada pekerja industri gerabah.Penelitian observasional analitik dengan rancangan studi potong lintang. Pada penelitian ini diperoleh subyek 60 orang, 53,3\% adalah laki-laki. Rerata usia 43,75tahun. Frekuensi kejadian DT pada penelitian sebesar 58,33\%. Pada uji bivariat riwayat atopik, wet work, dan lama kontak berhubungan secara bermakna dengan kejadian DT $(p<0,05)$. Dermatitis tangan yang muncul pada subyek kemungkinan disebabkan oleh kalsium oksida, aluminium oksida, dan kromium yang merupakan kandungan dari tanah liat sebagai bahan baku utama industri. Kesimpulan penelitian adalah frekuensi kejadian DT pada pekerja sebesar 58,33\% danTerdapat hubungan yang bermakna antara riwayat atopi, wet work, dan lama kerja terhadap DT pada pekerja gerabah
\end{abstract}

Kata Kunci : Dermatitis Tangan, Faktor Risiko, Riwayat Atopi, Wet Work, Lama Kontak, Gerabah

\section{ABSTRACT}

Hand dermatitis (HD) is a form of occupational dermatitis that frequently occurs. It is caused by exposure to chemicals and the environment. Hand dermatitis is often related to work and pottery industry was one of them. Clay as the main ingredient in the traditional pottery industry contains ingredients that potentially irritant and allergenic. The frequency and risk factors that affected the frequency of $H D$ in pottery industry worker was unknown. Objective of this study was to determine frequency and history of atopic, wet work, and contact duration as risk factors that affected that frequency of HD in traditional pottery industry worker. Analytic observational study with a cross-sectional design. Sixty subjects were included in this study, 53,3\% are men. The mean age of subjects was 43.75 years old. Frequency of HD on pottery industral worker was 58,33\%. In bivariate analysis, history of atopy, wet work, and contact duration were significantly associated with the incidence of hand dermatitis. Hand dermatitis that appears on the subject is probably caused by calcium oxide, aluminum oxide, and chromium which was the content of clay as the industry's main raw material. Conclusion of this study was frequency of hand dermatitis $58.33 \%$ and there was a significant association between a history of atopy, wet work, and contact duration with hand dermatitis among traditional pottery industry workers

Key word : Hand Dermatitis, Risk Factor, History Of Atopic, Wet Work, Contact Duration, Pottery

How To Cite: Pramuningtyas, R., \& Hudini, D. (2019). FAKTOR RISIKO DERMATITIS TANGAN PADA PEKERJA TRADISIOAL INDUSTRI GERABAH (SEBUAH STUDI OBSERVASIONAL). Biomedia, 11(1), 49-53. doi:https://doi.org/10.23917/biomedika.v11i1.7697

DOI: https://doi.org/10.23917/biomedika.v11i1.7697

\section{PENDAHULUAN}

Dermatitis tangan (DT) adalah bentuk dermatitis okupasional yang sering terjadi, karena tangan merupakan bagian tubuh yang paling sering terkena $(80 \%)$ akibat sering terpapar bahan kimia dan lingkungan (Nanko, 2004). Dermatitis tangan merupakan penyakit yang bersifat kronis dan sering relaps. Dermatitis tangan memiliki dampak yang besar pada pekerjaan, sosial dan psikologis penderita (Diepgen et al, 2007). 
Cvetkovski et al (2005) melaporkan bahwa dermatitis tangan menyebabkan ijin sakit yang berkepanjangan pada $19,9 \%$ penderita dan 23 persennya kehilangan pekerjaan. Hal ini terjadi terutama pada DT yang parah (Luk et al, 2011). Dermatitis tangan juga menimbulkan stigma sosial karena tangan adalah organ komunikasi dan ekspresi serta lokasinya mudah terlihat (Diepgen et al, 2007).

Prevalensi dermatitis tangan pada populasi umum sebesar $2-10 \%$ dan dipengaruhi oleh beberapa faktor risiko yaitu endogen maupun eksogen (Smith et al, 2003).Penyebab DT adalah multifaktorial(Andersen, 2003), Faktor endogen berupa faktor herediter, gangguan sistem imunologi, keadaan kulit penderita, vaskularisasi, hormonal, dan stres emosional.Sedangkan faktor eksogen berupa bahan alergen, iritan, cahaya, cuaca, dan infeksi (Rietschel and Fowler, 2001).Atopi telah diteliti sebagai faktor risiko DT.Sebuah studi epidemiologi menemukan $28 \%$ dari subyek dengan DT memiliki hay fever atau asma. Pasien dengan riwayat dermatitis atopi, 60\% sampai $70 \%$ akan berkembang menjadi DT. Kebanyakan individu tersebut akan mengalami keterlibatan tangan jika pekerjaan mereka melibatkan kontak teratur dengan bahan yang mengiritasi tangan seperti sabun dan air (Kedrowski and Waxshaw, 2008).Dermatitis tangan banyak berhubungan dengan beberapa jenis pekerjaan seperti pekerja di dapur, penata rambut, petugas kebersihan, perawat dan petugas kesehatan lainnya merupakan pekerjaan dengan wet work (Meding, 2004).

Daerah Istimewa Yogyakarta sebagai kota besar dengan kegiatan perekonomian tinggi memiliki banyak kegiatan industri tradisional. Salah satunya adalah industry gerabah.Penelitian sebelumnya oleh Rachmawati melaporkan kejadian DKI pada perajin gerabah di Jepara karena kandungan alumunium dan silika yang dapat mengiritasi kulit (Rachmawati, 2017). Tanah liat sebagai bahan bakuindustri gerabah diduga mengandung kromium, aluminium, dan silika yang dapat menyebabkan iritasi kulit (Winarno, 2016).

Berbagai publikasi yang melaporkan kejadian DT sulit dibandingkan karena perbedaan pada berbagai variabel, termasuk area geografis dan paparan spesifik (Andersen, 2003).

Hubungan riwayat atopik, wet work, dan lama kontak terhadap kejadian DT pada pekerja gerabah belum pernah dilaporkan.

\section{METODE}

Penelitian ini merupakan penelitian observasional analitik dengan rancangan studi potong lintang untuk mengetahui faktor risiko berperan terhadap kejadian DT dan frekuensi kejadian DT.Penelitian sudah disetujui oleh komisi etik Fakultas Kedokteran Universitas Muhammadiyah Surakarta.Dermatitis tangan adalah inflamasi pada tangan dengan satu gejala atau lebih berupa kemerahan dan bengkak pada tangan atau jari tangan, pecah-pecah dan bersisik atau kering pada tangan atau jari, lepuh atau bintil berair pada tangan atau sela jari, kemerahan dan pecah-pecah pada tangan atau jari tangan, serta pecah-pecah dan gatal pada tangan atau jari dan yang terjadi selama 12 bulan terakhir dan kronis (lebih dari 3 minggu) atau berulang (lebih dari sekali) yang diketahui berdasarkan kuesioner. Wet work didefinisikan sebagai kondisi di mana kulit terpapar cairan selama lebih dari 2 jam perhari, atau penggunaan sarung tangan oklusif $>2$ jam per hari atau cuci tangan lebih dari 20 kali per hari di lokasi kerja yang diketahui berdasarkan kuesioner. Instrumen lain yang digunakan adalah Nordic Occupational Skin Questionnaire (NOSQ-2002) untuk survey penyakit kulit akibat kerja dan paparan dari faktor lingkungan. Subyek penelitian adalah pekerja industri gerabah di Yogyakarta.Kriteria inklusi pada penelitian ini adalah telah bekerja minimal 2 tahun, berusia > 18 tahun, dan bersedia ikut serta dalam penelitian dan mengisi kuesioner penelitian.Sedangkan kriteria eksklusi adalah subjek sedang mengalami kelainan kulit lain dan atau sedang dalam pengobatan kortikosteroid topikal, kortikosteroid sistemik, dan antihistamin.Frekuensi DT disajikan dalam bentuk tabel demografik responden penelitian berupa jumlah dan persentase. Analisis bivariat menggunakan uji statistik chi square dengan interval kepercayaan 95\%. Analisis multivariat menggunakan teknik analisis regresi logistik untuk mengetahui semua hubungan variabel dan menentukan variabel bebas mana yang paling berpengaruh dengan variabel terikat.

\section{HASIL DAN PEMBAHASAN HASIL}

1. Karakteristik sosiodemografik responden

Subyek penelitian berjumlah 60 orang, 28 orang perempuan $(46,7 \%)$ dan 32 orang laki-laki $(53,3 \%)$. Usia subyek termuda 21 tahun dan tertua 70 tahun dengan rerata usia adalah 43,75 tahun. Data demografik dari responden ditampilkan pada tabel 1 . 
Tabel 1. Karakteristik Sosiodemografik Responden

\begin{tabular}{|c|c|c|c|}
\hline & & $\mathbf{N}$ & $\%$ \\
\hline \multicolumn{4}{|l|}{ Usia } \\
\hline $21-30$ & & 10 & (16.7) \\
\hline $31-40$ & & 17 & (28.3) \\
\hline $41-50$ & & 16 & (26.7) \\
\hline $51-60$ & & 11 & (18.3) \\
\hline $61-70$ & & 5 & $(8.3)$ \\
\hline $71-80$ & & 1 & (1.7) \\
\hline \multicolumn{4}{|l|}{ Jenis Kelamin } \\
\hline Perempuan & & 28 & (46.7) \\
\hline Laki-laki & & 32 & $(53.3)$ \\
\hline \multicolumn{4}{|l|}{ Jenis Pekerjaan } \\
\hline Finishing & & 12 & $(20.0)$ \\
\hline $\begin{array}{l}\text { Pembentukan } \\
\text { Gerabah }\end{array}$ & Badan & 48 & $(80.0)$ \\
\hline
\end{tabular}

Hasil pemeriksaan pada subyek penelitian diperoleh 35 dari 60 orang $(58,33 \%)$ menderita DT. Lokasi DT yang tersering adalah tangan dan diikuti lengan bawah.Seluruh responden dengan DT menyatakan bahwa keluhan membaik saat tidak bekerja.Sebagian besar responden memilih untuk membiarkan saja DT yang diderita tanpa diobati.

2. Analisis bivariat hubungan riwayat atopi, wet work, dan lama kontak dengan dermatitis tangan

Analisis bivariat dilakukan pada beberapa faktor risiko yang mempengaruhi DT. Variabel riwayat atopi, dengan uji chi square, didapatkan hubungan yang signifikan $(\mathrm{p}=0,012, \quad \mathrm{RP}$ $3,8(1.311$ - 11.474)). Hasil ini menunjukkan bahwa riwayat atopi memiliki risiko 3,8 kali dibandingkan tanpa riwayat atopi. Faktor risiko wet work dan lama kontak juga menunjukkan hubungan signifikan dengan nilai $\mathrm{p}<0,05$. Hubungan faktor risiko dengan kejadian DT dicantumkan pada tabel 2 .

Table 2. Analisis Bivariat

\begin{tabular}{rcccc}
\hline \multicolumn{1}{c}{ Variabel } & Responden & $\begin{array}{c}\text { Dermatitis } \\
\text { tangan } \\
(+)\end{array}$ & $\begin{array}{c}\text { Dermatitis } \\
\text { Tangan } \\
(-)\end{array}$ & $\boldsymbol{p}$ \\
\hline $\begin{array}{l}\text { Riwayat } \\
\text { Atopik }\end{array}$ & $33(55 \%)$ & $24(68,6 \%)$ & $9(36 \%)$ & 0.012 \\
Ya & $27(45 \%)$ & $11(31,4 \%)$ & $16(64 \%)$ & \\
Tidak & & & & \\
\hline Wet work & & & & \\
Ya & $43(71,7 \%)$ & $29(82,8 \%)$ & $14(56 \%)$ & 0,023 \\
Tidak & $17(28,3 \%)$ & $6(17,1 \%)$ & $11(44 \%)$ & \\
\hline $\begin{array}{c}\text { Lama Kontak } \\
\text { (Jam/hari) } \\
<8 \text { jam/hari }\end{array}$ & $17(28,3 \%)$ & $5(14,3 \%)$ & $12(48 \%)$ & 0,004 \\
$\geq 8$ jam/hari & $43(71,7 \%)$ & $30(85,7 \%)$ & $13(52 \%)$ & \\
\hline & & & & \\
\hline
\end{tabular}

\section{Analisis multivariat}

Syarat variabel yang dapat digunakan untuk analisis regresi logistik adalah variabel yang memiliki nilai $\mathrm{P}<0.25$. Hasil uji regresi logistik variabel tersebut sebagai berikut :
Tabel 3. Hasil Analisis Multivariat Faktor Risiko

\begin{tabular}{lc}
\hline \multicolumn{1}{c}{ Variabel } & $\boldsymbol{p}$ \\
\hline Riwayat atopik & 0,018 \\
Wet Work & 0,125 \\
Lama Kontak & 0,038 \\
\hline
\end{tabular}

Berdasarkan analisis multivariat pada tabel 3, dapat diketahui bahwa variabel yang berpengaruh pada terjadinya dermatitis tangan dengan tingkat pengaruh yang terbesar adalah riwayat atopik diikuti oleh lama kontak.

\section{PEMBAHASAN}

Frekuensi DT pada penelitian ini sebesar 58,33\%. Angka ini lebih tinggi dibandingkan kejadian DT pada perajin tradisional menggunakan daun pandan di Kulonprogo sebesar 24,3\%, Pada penelitian ini, hasil analisis statistikusia dan jenis kelamin tidak berpengaruh secara signifikan terhadap kejadian DT. Jenis kelamin tidak berpengaruh terhadap kejadian DT walaupun sebagian besar penderita DT adalah laki-laki.Berdasarkan penelitian eksperimental dan epidemiologi, kulit perempuan tidak lebih sensitif terhadap iritasi dari kulit lakilaki.Perbedaan kejadian DT antara laki-laki dan perempuan tidak disebabkan karena perbedaan fungsi barier kulit, tetapi lebih karena perbedaan paparan eksternal.(Hald, 2009).

Faktor risiko usia pada penelitian ini terbukti tidak berhubungan secara signifikan dengan kejadian DT. Rata-rata usiasubjek dengan DT dan tanpa DT hampir sama sehingga hasil uji statistik usia tidak berpengaruh secara signifikan terhadap kejadian DT. Sebagian besar subyek penelitian dengan DT berusia diatas 40 tahun. Taylor et al menyebutkan bahwa setelah usia 30 tahun, produksi hormon-hormon penting seperti testosteron, hormon pertumbuhan, dan estrogen mulai menurun, sedangkan hormon-hormon tersebut berpengaruh terhadap kesehatan kulit. Sehingga bersamaan dengan meningkatnya usia, menurunnya hormon-hormon tadi mempengaruhi kesehatan pada kulit.

Riwayat atopik berhubungan secara signifikan dengan kejadian DT.Banyak penelitian pada populasi umum melaporkan bahwa riwayat atopik merupakan faktor risiko yang paling penting untuk DT (Thyssen,2010). Kondisi atopi meningkatkan kerentanan dermis terhadap bahan iritan dan menghambat proses penyembuhan (Smith et al, 2004). Stratum korneum yang intak, lapisen barier pelindung dari sel epidermis yang mengalami keratinisasi dan kompak, memiliki peran yang penting untuk mencegah terjadinya DKI dan DKA (Antezana and Parker, 2003). 
Tanaka et al (1998) melaporkan bahwa individu dengan atopik mempunyai penurunan hidrasi pada stratum korneum dan rendahnya kandungan asam amino pada kulit, sehingga akan lebih mudah masuknya bahan, baik yang bersifat iritan maupun alergen. Pada penelitian kohort prospektif yang dilakukan oleh Diepgen et al menunjukkan bahwa atopik skin diathesis meningkatkan kemungkinan berkembangnya dermatitis tangan dengan odd rasio 2:1 (Belsito, 2005).

Wet work memiliki hubungan yang signifikan dengan kejadian DT.Wet work dalam hal ini berhubungan dengan air dan detergen.Pekerjaan yang membutuhkan seringnya kontak dalam air menyebabkan maserasi dan larutnya lipid stratum korneum (Antezana and Parker, 2003).Over hidrasi stratum korneum meningkatkan penetrasi material asing dan berperan terhadap terjadinya dermatitis kontak iritan dan dermatitis kontak alergi (Tsai and Maibach, 1999).Selain itu meningkatnya frekuensi cuci tangan merupakan faktor risiko penting terjadinya dermatitis tangan (Smith et al, 2003).Denaturasi protein stratum korneum, perubahan lipid interseluler (deplesi atau reorganisasi lipid), berkurangnya kohesi korneosit, dan berkurangnya kapasitas pengikatan air dari stratum korneum merupakan mekanisme kerusakan kulit akibat kontak dengan detergen cuci tangan (Larson et al, 2006).

Berdasarkan hasil analisis statistik antara lama kontak dengan kejadian DT, didapatkan perajin gerabah yang lama kontak $\geq 8$ jam/hari yang mengalami DT sebanyak 30 orang $(69.8 \%)$. Berdasarkan hasil uji chi square, didapatkan nilai $P$ yaitu sebesar 0.004 , karena nilai $P<0.05$ maka dapat disimpulkan bahwa terdapat hubungan yang bermakna antara lama kontak dengan kejadian dermatitis tangan pada perajin gerabah. Penelitian ini mendukung penelitian Nuraga et al. (2008), bahwa semakin lama kontak dengan bahan kimia maka peradangan atau iritasi kulit dapat terjadi dan menyebabkan kelainan kulit. Penelitian tersebut menyebutkan bahwa lama kontak responden dengan bahan kimia sebanyak 8 jam/hari terjadi pada 45 pekerja $(83 \%)$, ratarata 6 jam/hari 1 orang (2\%), rata-rata 3 jam/hari 1 (2\%), dan rata-rata 2 jam/hari 7 orang (13\% (Nuraga et al, 2008). Semakin lama kontak dengan bahan iritan maupun alergen, maka dapat terjadi peradangan atau iritasi kulit sehingga menyebabkan sel kulit lapisan luar dapat mengalami kerusakan yang lebih dalam (Lestari and Utomo, 2007).

Kemungkinan penyebab dermatitis tangan pada pekerja gerabah adalah beberapa kandungan bahan dalam tanah liat sebagai bahan baku utama. Kandungan lempung atau tanah liat di gerabah kasongan salah satunya adalah kalsium oksida. Kalsium oksida $(\mathrm{CaO})$ saat bersentuhan dengan air akan berubah menjadi kalsium hidroksida $(\mathrm{Ca}(\mathrm{OH}) 2)$, yang merupakan substansi bersifat sangat basa, dengan nilai $\mathrm{pH}$ 11-13 dan dapat mengakibatkan iritasi yang sangat kuat pada kulit, serta dapat menyebabkan erosi kulit dan bahkan nekrosis kulit (Wang, et al., 2011). Selain kandungan kalsium hidroksida, lempung kasongan memiliki kandungan $\mathrm{Al} 2 \mathrm{O} 3$ (aluminium oxide) sebanyak 20,09\%. Aluminium oksida dilaporkan menyebabkan dermatitis kontak sistemik pada penggunaan pasta gigi yang mengandung aluminium oksida dalam kadar $30 \%$ sampai 40\% (Rietschel dan Fowler, 2001). Gerabah kasongan juga memiliki kadar chromium oxide sebanyak $0,025 \%$ (Winarno, 2016). Studi di Eropa dan Amerika Serikat telah menunjukkan bahwa tingkat prevalensi hipersensitivitas kromium di antara pekerja semen sekitar $45 \%$. Penelitian (Wang, et al., 2011) menunjukkan tingkat positif hipersensitivitas kromium di antara pekerja semen setinggi $24,5 \%$. Selain pada semen, kromium juga didapatkan pada tanah liat. Tanah liat merupakan bahan baku pokok untuk membuat gerabah. Untuk mendeteksi keberadaan allergen atau iritan dalam suatu bahan, dapat dilakukan beberapa analisa kimia seperti kromatografi lapis tipis, kromatografi gas, dan spektrofotometri (Lachapelle and Maibach, 2009).

\section{SIMPULAN DAN SARAN}

Frekuensi DT pada pekerja gerabah adalah58,33\%. Faktor risiko yang memiliki hubungan yang signifikan terhadap kejadian DTadalah riwayat atopi, wet work, dan lama kontak.Bahan yang diduga menyebabkan DT pada penelitian ini adalah kalsium oksida, aluminium oksida, dan kromium yang merupakan kandungan dari tanah liat sebagai bahan baku utama industri. Saran penelitian ini adalah perlu dilakukan penelitian lebih lanjut tentang bahan/senyawa yang bertanggung jawab terhadap kejadian DT dengan cara uji kualitas, identifikasi dan purifikasi tanah liat. 


\section{DAFTAR PUSTAKA}

Andersen, K.E. 2003. Occupational issues of allergic contact dermatitis. International archives of Occupational Environmental Health; 76: 347-50

Antezana, M., and Parker, F. 2003. Occupational contact dermatitis. Immunology and Allergy Clinics of North America; 23: 269- 90

Belsito, D.V. 2005. Occupational contact dermatitis: Etiology, prevalence, and resultant impairment/disability. Journal of the American Academy of Dermatology; 53:303-13

Cvetkovski, R.S., Rothman, K.J., Olsen, J., Mathiesen, B., Iversen, L., Johansen, J.D., et al. 2005. Relation between diagnoses on severity, sick leave and loss of job among patients with occupational hand eczema. British Journal of Dermatology: 152: 93-98.

Diepgen, T.L., Agner, T., Aberer, W., Berth-Jones, J., Cambazard, F., Elsner, P, et al. 2007. Management of chronic hand eczema. Contact Dermatitis; 57: 203-10.

Hald, M. 2009. Hand eczema - severity and medical attendance in relation to prognosis. $\mathrm{PhD}$ thesis. Copenhagen: Gentofte University Hospital University of Copenhagen

Kedrowski, D.A., and Waxshaw, E.M., 2008. Hand dermatitis: a review of clinical features, diagnosis, and management. Dermatology Nursing; 20: 17-25

Lachapelle, J.M., and Maibach, H.I. 2009. The spectrum of disease for which patch testing is recommended. In: Lachapelle, J.M., Maibach, H.I. Patch testing and prick testing. Second edition.Springer.Jerman.

Larson, E., Girard, R., Pessoa-Silva, C.L., Boyce, J., Donaldson, L., Pittet, D. 2006. Skin reactions related to hand hygiene and selection of hand hygiene products. American Journal Infection Control; 34: 627-35.

Lestari , F. and Utomo, H. S., 2007. Faktor-faktor yang Berhubungan dengan Dermatitis Kontak Pada Pekerja di PT Inti Pantja Press Industri.. Makara Kesehatan, Vol. 11, No. 2.

Luk, N.M., Lee, H.C., Luk,C.K., Cheung,Y.Y., Chang, M.C., Chao,V.K., dkk. 2011. Hand eczema among Hong Kong nurses: a self-report questionnaire survey conducted in a regional hospital. Contact Dermatitis; 65: 329-35.

Meding, B., Jarvholm, B. 2004. Incidence of hand eczema - a population-based retrospective study.The Journal of Investigative dermatology; 122: 873-7

Nanko, H. 2004. Treatment of housewives' hand eczema - touching on recent topics.Japan Medical Association Journal; 47(1): 44-51.

Nuraga, W., Lestari, F., Kurniawidjaja, L. M., 2008. Dermatitis Kontak pada Pekerja yang Terpajan dengan Bahan Kimia di Perusahaan Industri Otomotif Kawasan Industri Cibitung Jawa Barat. Makara Kesehatan, 12(2), pp. 63-

Rachmawati, D. K., 2017. Faktor-Faktor Yang Berhubungan Dengan Kejadian Dermatitis Kontak Iritan Pada Pengrajin Gerabah, Semarang: Thesisundergraduate Universitas Muhammadiyah Semarang.

Rietschel, R.L., and Fowler, J.F. 2001.Contact dermatitis and other reaction to metals.Dalam :Fisher's Contact Dermatitis. Edisi Kelima. Philadelphia: Lippincott Williams and Wilkins. 639 - 49

Smith, D.R., Ohmura, K., Yamagata, Z. 2003. Prevalence and correlates of hand dermatitis among nurses in a Japanese Teaching Hospital. Journal of Epidemiology; 13: 157-61. 
Tanaka, M., Okada, M., Zhen, X.Y., Inamura, N., Kitano, T., Shirai, S. 1998. Decreased hydration state of the stratum corneum and reduced amino acid content of the skin surface in patient with seasenal allergic rhinitis. British Journal of Dermatology; 139: 618-21

Taylor, J.S., Sood, A., Amado, A. 2007. Occupational Skin Disease. Dalam: Wolff, K., Goldsmith, L.A., Katz, S.I., Gilchrest, B.A., Paller, A.S., Leffell, D.J. Fitzpatrick's Dermatology in General Medicine. Edisi ketujuh.Volume 2. New York: McGraw-Hill Inc. 2067-73

Thyssen, J.P., Johansen, J.D., Linneberg, A., Menne, T. 2010. The epidemiology of hand eczema in the general population - prevalence and main findings.Contact Dermatitis; 62: 75-87

Tsai, T.F., Maibach, H.I. 1999. How irritant is water? An overview.Contact Dermatitis; 41: 311-4

Wang, B.J., Wu, J.D., Sheu, S.C., Shih, T.S., Chang, H.Y., Guo, Y.L., Wang, Y.J., Chou, T.C., 2011. Occupational hand dermatitis among cement. Journal of the Formosan Medical Association, pp. 775-779.

Winarno, T., 2016. Perbandingan Karakteristik Lempung Kasongan dan Godean Sebagai Bahan Baku Industri Gerabah Kasongan. Teknik, 37 (1)(p-ISSN 0852-1697, e-ISSN: 2460-9919), pp. 4146 . 